\title{
Therapeutic potential of mesenchymal stem cells in gastrointestinal cancers - current evidence
}

This article was published in the following Dove Press journal:

Gastrointestinal Cancer: Targets and Therapy

8 September 2016

Number of times this article has been viewed

\author{
Jiwei Qin' \\ Yue Zhao ${ }^{2}$ \\ Yan Wang' \\ Christopher Betzler ${ }^{2}$ \\ Felix C Popp ${ }^{2}$ \\ Arvid Sen Gupta ${ }^{2}$ \\ Daniela Augsburger ${ }^{2}$ \\ Peter Camaj ${ }^{2}$ \\ Peter J Nelson ${ }^{3}$ \\ Christiane J Bruns ${ }^{2}$ \\ 'Department of Surgery, University \\ of Munich, Munich, Germany; \\ ${ }^{2}$ Department of Surgery, Otto-von- \\ Guericke University, Magdeburg, \\ Germany; ${ }^{3}$ Clinical Biochemistry \\ Group, Medizinische Klinik und \\ Poliklinik IV, University of Munich, \\ Munich, Germany
}

\begin{abstract}
Mesenchymal stem (or stromal) cells (MSCs) are nonhematopoietic progenitor cells that can be obtained from bone marrow and adipose tissue. Due to the ability of MSCs to migrate to damaged and cancerous tissue, this behavior of MSCs has been exploited as a tumor-targeting strategy for cell-based cancer therapy to improve the efficacy and minimize the toxicity of current gene therapy approaches in the treatment of cancers. In this review, we focus on the current developments of MSC-based gene therapy in gastrointestinal cancer studies, in particular, the role of MSCs as tumor-targeted therapy vehicles and the prospects in their clinical application.
\end{abstract}

Keywords: mesenchymal stem cells, gastrointestinal cancers, cancer therapy

\section{Introduction}

Mesenchymal stem cells (MSCs) are a group of heterogeneous multipotent cells, which can be isolated from many tissues such as bone marrow, ${ }^{1}$ peripheral blood, ${ }^{2}$ and adipose tissue. ${ }^{3}$ These do have the potential to treat a wide range of diseases. ${ }^{4}$ MSCs have the same self-renewal characteristics as undifferentiated cells and are characterized as adherent cells that have the ability to differentiate into osteocytes, fibroblasts, adipocytes, chondrocytes, and marrow stroma. ${ }^{1,5}$ For their regenerative potential and immune-suppressive capacity, MSCs can be used in regenerative medicine, ${ }^{6,7}$ tissue transplantation, ${ }^{8-10}$ and cancer therapy. ${ }^{4,11}$

The surface markers to identify MSCs are different among these cells because they originate from different tissues or are cultured in different conditions. ${ }^{12,13}$ The Mesenchymal and Tissue Stem Cell Committee of the International Society proposes minimal criteria to define human MSCs for MSC therapy, which have to fulfill a standardized phenotype for cellular therapies. ${ }^{14}$ These criteria include the expression of CD105, CD90, and CD73, but not CD79a, CD45, CD34, CD19, CD14, CD11b, and HLA-DR. ${ }^{5,15,16}$

\section{The migration of MSCs to tumor}

A number of studies have shown that MSCs do migrate to sites of injury, ischemia, and tumor microenvironments. The mechanisms by which MSCs migrate across the endothelium and home to the target tissues are not yet fully understood. It may be related to the MSC receptors, the target tissue, and the cell surface receptors. It is shown that homing of MSCs is dependent on chemokine receptors such as CXCR4, c-Met, VEGFR, PDGFr, and CCR2. SDF-1, and its receptor CXCR4 have been previously
Correspondence: Christiane J Bruns Department of Surgery, Otto-vonGuericke University, Magdeburg,

Leipziger Straße 44, 39120

Magdeburg, Germany

Email christiane.bruns@med.ovgu.de
Gastrointestinal Cancer: Targets and Therapy 2016:6 4I-47

(c) (i) (5) $\odot 2016$ Qin et al. This work is published by Dove Medical Press Limited, and licensed under Creative Commons Attribution - Non Commercial (unported, v3.0) License. The full terms of the License are available at http://creativecommons.org/licenses/by-nc/3.0/. Non-commercial uses of the work are permitted without any further perms how to request permission may be found at: http://www.dovepress.com/permissions.php 
characterized in MSC homing. ${ }^{17-21}$ It has been shown that freshly isolated MSCs have the best homing ability, and their homing efficiency gets worse with rising passage numbers. ${ }^{22}$ Some studies demonstrated that the use of cytokines (IL [interleukin]-6, IL-1 $\beta$, hepatocyte growth factor [HGF], etc) to pretreat the cultured MSCs will enhance the expression of chemokines and increase the homing effect of MSCs. ${ }^{23-25}$ Several studies also suggest that MSCs are attracted to sites of irradiation. ${ }^{26-28}$ In a recent study, François et $\mathrm{al}^{28}$ used total body irradiation (TBI) with or without additional local irradiation to research the potential therapeutic efficacy of MSCs for irradiation damage. They found that not only did TBI induce an increase of engraftment levels of human MSCs (hMSCs) in the brain, heart, bone marrow, and muscles, but also more MCSs migrated to the exposed area of local irradiation after TBI as compared to TBI alone. ${ }^{28}$

\section{MSCs in gastrointestinal cancer therapy The biological function of MSCs on cancer}

In a number of studies, MSCs have been shown to migrate to the tumor site and demonstrate antitumor effects both in vitro and in different cancer mouse models. ${ }^{29}$ Kidd et $\mathrm{al}^{30}$ observed that in an in vivo model of pancreatic cancer, intraperitoneally injected hMSCs migrated to primary and metastatic tumor sites and potentially inhibited tumor growth. Maestroni et $\mathrm{al}^{31}$ also showed that coinjection of mouse MSCs with tumor cells can decrease the tumor volume. In some studies for hepatocellular cancer (HCC), MSCs were able to inhibit the tumor growth in vivo and decrease the cell proliferation while increasing apoptosis via downregulation of NFKB- or Wnt-signaling pathways. ${ }^{32,33}$

However, several other studies with different types of tumors have demonstrated that MSCs can promote tumor growth or metastasis and are related to the formation of tumor-supporting stroma. ${ }^{34-36}$ More specifically, it has been reported that nontherapeutic MSCs enhanced tumor growth on HCC cells in vivo. ${ }^{37}$ Similarly, Zhu et $\mathrm{al}^{38}$ showed that MSCs could enhance the invasive capacity of cancer cells via extensive angiogenesis and tumor cell protection of immune cell recognition. ${ }^{39}$

Furthermore, MSCs appear to have a complex biology. Li et $\mathrm{al}^{40}$ reported that hMSCs could significantly enhance tumor growth in vivo in a HCC subcutaneous model, but decrease the number of lung metastases, while the same cell type enhanced proliferation but inhibited invasiveness in vitro. It has also been shown that the promoting role of hMSCs on esophageal cancer growth in vivo was related to an increase of tumor vessel formation, whereas MSCs were found to inhibit proliferation and invasion of esophageal cancer cells in vitro. ${ }^{41}$ Thus, the role of MSCs seems to be controversial in carcinogenesis.

\section{The use of MSCs as tumor-targeted therapy vehicles}

In recent years, there has been considerable interest in the use of MSCs as delivery vehicles for antitumor drugs, proteins, and other therapeutic agents because of the homing abilities and the fact that MSCs can evade host immune response. ${ }^{42}$ The systemic use of these biologic agents in cancer therapy is generally limited due to their short biologic half-life and toxicity at the required therapeutic dose (Table 1$){ }^{43}$

\section{Immunostimulatory agents}

IL-12 is a pleiotropic cytokine that exerts potent antitumor activity and creates an interconnection between the innate and adaptive immunity. ${ }^{44,45}$ Three kinds of tumor models containing melanoma, Lewis lung cancer (LLC) and HCC were established by Chen et al; ${ }^{46}$ they injected IL-12 geneengineered MSCs into the $\mathrm{C} 57 \mathrm{BL} / 6$ and $\mathrm{BALB} / \mathrm{c}$ mice before tumor cell inoculation. Then the mice were divided into three groups with 12 mice per group. There were only three mice in all three groups that presented a tumor (one in the HCC group and two in the LLC group), while almost all mice without IL-12-gene-engineered MSCs developed tumors. ${ }^{46}$ IL- 15 is a cytokine with structural similarity to IL- $2^{47}$ and can rapidly be released by tumor-associated and tumor-infiltrating macrophages induced by IL-12. ${ }^{48,49}$ This could be a tool for cancer immunotherapy because of the effect of maintaining long-lasting T-cell antitumor immunity. ${ }^{50-52}$ Jing et al ${ }^{53}$ found out that IL-15-transduced MSCs could inhibit tumor growth and prolong the survival of mice that bear pancreatic tumors by inducing natural killer (NK) cell and T-cell accumulation. The cytokine interferon (IFN)- $\beta$ is known to have potent proapoptotic effects and is capable of inhibiting both tumor growth and angiogenesis..$^{54,55}$ Kidd et al ${ }^{30}$ showed that engineered hMSCs expressing IFN- $\beta$ are able to produce the biological agents locally at the tumor site and in this way inhibit the growth of pancreatic cancer in vivo.

\section{Prodrug}

Prodrugs are inactive compounds, which convert nontoxic prodrugs into toxic antimetabolites to produce a toxic 
Table I Selected preclinically engineered MSC-based cancer therapy studies in gastrointestinal cancers

\begin{tabular}{|c|c|c|c|}
\hline Transfected products & MSCs & Tumor & Effects \\
\hline \multicolumn{4}{|l|}{ Immunostimulatory agents } \\
\hline IL-I2 & Mouse BM-MSCs (intraperitoneal) & Hepatocellular carcinoma ${ }^{46}$ & Tumor prevention \\
\hline IL-I5 & Human UC-MSCs (iv) & Pancreatic cancer ${ }^{53}$ & $\begin{array}{l}\text { Inhibit tumor growth and prolong } \\
\text { survival }\end{array}$ \\
\hline INF- $\beta$ & Human BM-MSCs (iv) & Pancreatic cancer ${ }^{30}$ & Inhibit tumor growth \\
\hline \multicolumn{4}{|l|}{ Prodrug } \\
\hline $\mathrm{CD} / 5-\mathrm{FC}$ & Human BM-MSCs (iv) & Gastric cancer $^{57}$ & Inhibit tumor growth \\
\hline \multirow[t]{2}{*}{ TK/GCV } & Mouse BM-MSC (iv) & Pancreatic cancer ${ }^{35,36}$ & $\begin{array}{l}\text { Inhibit tumor growth, prolong } \\
\text { survival, and reduce liver metastases }\end{array}$ \\
\hline & & Hepatocellular cancer ${ }^{37}$ & Inhibit tumor growth \\
\hline \multicolumn{4}{|l|}{ Cytotoxic agents } \\
\hline \multirow[t]{5}{*}{ TRAIL } & $\begin{array}{l}\text { Human BM-MSCs (coimplantation } \\
\text { with tumor cells sc) }\end{array}$ & Colorectal cancer ${ }^{63}$ & Inhibit tumor growth \\
\hline & Human BM-MSC (iv) & Colorectal cancer ${ }^{64}$ & Inhibit tumor growth \\
\hline & Human AT-MSCs (iv) & Colorectal cancer ${ }^{65}$ & Inhibit tumor growth \\
\hline & Rat BM-MSCs (sc) & Hepatocellular cancer ${ }^{67}$ & $\begin{array}{l}\text { Inhibit tumor growth and prolong } \\
\text { survival }\end{array}$ \\
\hline & Human UC-MSCs (iv) & Hepatocellular cancer ${ }^{68}$ & Inhibit tumor growth \\
\hline \multicolumn{4}{|l|}{ Growth factor antagonists } \\
\hline NK4 & Human BM-MSCs (iv) & Gastric cancer ${ }^{72}$ & Inhibit tumor growth \\
\hline
\end{tabular}

Abbreviations: BM-MSCs, bone marrow-derived mesenchymal stem cells; UC-MSCs, umbilical cord-derived MSCs; AT-MSCs, adipose tissue-derived MSCs; iv, intravenous; sc, subcutaneous; MSCs, mesenchymal stem cells.

antitumor effect. It has been shown that prodrugs possess some advantages over conventional drugs, such as increased solubility, improved permeability and bioavailability, reduced adverse effects, and prolonged half-lives. ${ }^{56}$ You et al engineered human adipose tissue-derived MSCs to express the suicide gene cytosine deaminase::uracil phosphoribosyltransferase (CD::UPRT) which can convert the relatively nontoxic 5-fluorocytosine (5-FC) into the highly toxic antitumor 5-fluorouracil (5-FU). ${ }^{57}$ It has been demonstrated that hMSCs express the prodrug-activating enzyme $\mathrm{CD}$ that is able to convert the prodrug 5-FC into 5-FU, which shows anticancer therapeutic potential in vitro and in vivo. ${ }^{57}$ The combined use of the prodrug ganciclovir (GCV) and thymidine kinase of the herpes simplex virus (HSV-Tk) is commonly used in antitumor therapy. GCV is an analog nucleotide that can be phosphorylated into a monophosphate GCV by HSV-Tk. So when cells are transfected with the HSV-Tk gene, endogenous kinases will then change the monophosphate GCV into the active bi- and triphosphate GCV, which will block the cell cycle and induce apoptosis through inhibiting DNA synthesis ${ }^{58-60}$ Furthermore, transfected MSCs exposed to GCV can kill adjacent tumor cells via bystander effect; this effect is reliant on the transfer of monophosphate GCV between cells via gap junctions. ${ }^{61,62}$ Recently, our group found that engineered MSCs expressing HSV-Tk under the control of the CCL 5 or Tie2/Tek promoter could significantly inhibit the growth of pancreatic, ${ }^{35,36}$ breast, ${ }^{35}$ and hepatocel- lular carcinoma ${ }^{37}$ as well as incidence of metastases in vivo. CCL5 act as chemoattractant and is associated to increased tumor neovascularization. The Tie2/Tek gene encodes an angiopoietin receptor tyrosine kinase, essential for blood vessel formation. ${ }^{35-37}$

\section{Cytotoxic agents and growth factor antagonists}

Tumor necrosis factor-related apoptosis-inducing ligand (TRAIL), a member of the TNF family, is considered as a potential agent for cancer therapy due to its ability to induce apoptosis in a variety of cancer cells without affecting the majority of normal human cells..$^{43}$ In recent studies, engineered MSCs were used as a vehicle to deliver TRAIL that lead to colorectal, ${ }^{63-65}$ pancreatic, ${ }^{65,66}$ and $\mathrm{HCC}^{67-69}$ cell apoptosis and death in vitro and were able to significantly reduce tumor growth in vivo. HGF is a heterodimeric molecule, which promotes tumor growth, and is also a mesenchymal or stromal-derived mediator with angiogenic activity. As an antagonist of HGF receptors, NK4 inhibits cell proliferation and induces apoptosis through antagonizing the $\mathrm{HGF}^{70}$ and promotes antiangiogenic activities through the competitive inhibition of angiogenic growth factors to endothelial cells. ${ }^{71}$ In a gastric cancer study, Zhu et $\mathrm{al}^{72}$ found that MSCs transduced with NK4 could obviously inhibit the growth of gastric cancer in vivo by decreasing the microvessel density of tumor xenografts and by inducing apoptosis of tumor cells. 


\section{Synergistic approaches utilizing MSCs combined with radiation therapy}

The irradiation technique has resulted in a wide application of radiation therapy in gastrointestinal cancer. It is known that radiation therapy is associated with radiation exposure of surrounding healthy tissues and the development of acute injury, followed by late structural and/or functional damage. ${ }^{73}$ Recent studies showed that local irradiation not only induced homing of MSCs at exposed sites but also promoted their widespread engraftment to multiple organs. ${ }^{28}$ Chapel et al ${ }^{74}$ further found a potential role of the MSCs contribution to the repair process in various tissues after irradiation. Zielske et $\mathrm{al}^{75}$ demonstrated that the radiation-induced injury could be used to target MSCs to tumors, which might increase the effectiveness of MSC cancer gene therapy. These findings suggested that radiation therapy combined with the MSCs was able to increase the therapeutic efficacy. A novel application was shown by Knoop et $\mathrm{al}^{76}$ in an $\mathrm{HCC}$ xenograft mouse model by using sodium-iodide symporter (NIS) MSCs as an ideal gene delivery vehicle. Three cycles of systemic MSCmediated NIS gene delivery followed by ${ }^{131} \mathrm{I}$ application resulted in a significant delay in tumor growth. ${ }^{76}$ Therefore, the combined application of irradiation and MSCs should promote the therapeutic potential of engineered MSC cancer therapy without a damage of irradiation on $\mathrm{MSCs},{ }^{77}$ and the continued irradiation after the treatment of MSCs might improve the effective duration and extend the treatment cycle as well.

\section{Conclusion}

Stem cell transplantation has gained considerable interest during the past decade, as an alternative therapeutic tool in regenerative medicine and anticancer treatment. Several issues related to MSC therapy still remain unknown and are urgently needed to be defined: cellular mechanisms, precise operating method, and timing of MSC application. MSCs can easily be obtained and maintained. They do migrate to the sites of injury, ischemia, and tumor and have immunoprivileged properties that rely on the surrounding microenvironment. These functions are not only related to different cytokines and receptors, but also to cell-cell interaction. Therefore, MSCs can be used as vehicles for tumor-targeting therapies that might overcome the limitations of existing cell therapy approaches, which cannot inhibit the tumor precisely and specifically. There are a number of clinical trials utilizing MSCs for cancer therapy (Tables 2 and 3). Some of them start to use engineered MSCs, though most of these trials still use normal MSCs. In a recent clinical trial, genetically modified autologous MSCs from eligible patients will be used to treat advanced gastrointestinal or hepatopancreatobiliary adenocarcinoma. ${ }^{71}$

The safety of MSC utilization must be considered and will be the major hurdle for their practical use in clinical settings due to the dual effects of MSCs concerning tumors. There is still the necessity to proceed with more studies to demonstrate the specific mechanisms concerning the relation between MSCs and tumors.

Table 2 Clinical cancer trials utilizing therapeutic MSCs registered in the US National Institute of Health

\begin{tabular}{|c|c|c|c|c|}
\hline Identifier & Title & Condition & Enrollment & Phase \\
\hline NCT0I983709 & $\begin{array}{l}\text { Allogeneic human bone marrow-derived } \\
\text { mesenchymal stem cells in localized prostate } \\
\text { cancer (MSC) }\end{array}$ & Prostate cancer & $\begin{array}{l}\text { Currently recruiting } \\
\text { participants }\end{array}$ & Phase I \\
\hline NCTOI 275612 & $\begin{array}{l}\text { Mesenchymal stem cells in cisplatin-induced } \\
\text { acute renal failure in patients with solid organ } \\
\text { cancers (CIS/MSC08) }\end{array}$ & $\begin{array}{l}\text { Solid tumors } \\
\text { Acute kidney injury }\end{array}$ & $\begin{array}{l}\text { Currently recruiting } \\
\text { participants }\end{array}$ & Phase I \\
\hline NCT0I854567 & $\begin{array}{l}\text { P3 study of umbilical cord blood cells } \\
\text { expanded with MPCs for transplantation in } \\
\text { patients with hematologic malignancies }\end{array}$ & $\begin{array}{l}\text { Acute myelogenous leukemia } \\
\text { Acute lymphoblastic leukemia } \\
\text { Non-Hodgkin's lymphoma } \\
\text { Hodgkin's disease }\end{array}$ & $\begin{array}{l}\text { Currently recruiting } \\
\text { participants }\end{array}$ & Phase III \\
\hline NCT007904I3 & $\begin{array}{l}\text { Haploidentical stem cell transplantation in } \\
\text { neuroblastoma }\end{array}$ & Neuroblastoma & $\begin{array}{l}\text { Currently recruiting } \\
\text { participants }\end{array}$ & Phase 0 \\
\hline NCT02068794 & $\begin{array}{l}\text { MV-NIS-infected mesenchymal stem cells in } \\
\text { treating patients with recurrent ovarian cancer }\end{array}$ & Ovarian cancer & $\begin{array}{l}\text { Ongoing, but not } \\
\text { recruiting participants }\end{array}$ & Phase I/II \\
\hline NCT00408590 & $\begin{array}{l}\text { Recombinant measles virus vaccine therapy and } \\
\text { oncolytic virus therapy in treating patients with } \\
\text { progressive, recurrent, or refractory ovarian } \\
\text { epithelial cancer or primary peritoneal cancer }\end{array}$ & $\begin{array}{l}\text { Ovarian cancer } \\
\text { Primary peritoneal cavity } \\
\text { cancer }\end{array}$ & $\begin{array}{l}\text { Ongoing, but not } \\
\text { recruiting participants }\end{array}$ & Phase I \\
\hline NCT02079324 & $\begin{array}{l}\text { Genetically modified mesenchymal stem cell } \\
\text { therapeutic against head and neck cancer (GX-05I) }\end{array}$ & Head and neck cancer & $\begin{array}{l}\text { Ongoing, but not } \\
\text { recruiting participants }\end{array}$ & Phase I \\
\hline
\end{tabular}

Abbreviations: MPC, mesenchymal progenitor cells; MSC, mesenchymal stem cell; MV-NIS, measles virus encoding the thyroidal sodium-iodide symporter. 
Table 3 Clinical cancer trials utilizing therapeutic MSCs conducted in the European Union

\begin{tabular}{|c|c|c|c|c|}
\hline EudraCT number & Title & Condition & Enrollment & Phase \\
\hline $20|1-00| 822-8 \mid$ & $\begin{array}{l}\text { Infusion of third-party mesenchymal stem cells } \\
\text { after renal or liver transplantation: a Phase I-II, } \\
\text { open-label, clinical study }\end{array}$ & $\begin{array}{l}\text { Liver failure: end-stage liver diseases } \\
\text { Kidney failure: end-stage renal diseases }\end{array}$ & Ongoing & Phase I/II \\
\hline $20|2-00374|-15$ & $\begin{array}{l}\text { Treatment of advanced gastrointestinal cancer in } \\
\text { a Phase I/II trial with modified autologous MSC_- } \\
\text { apceth_I0I. Open-label, multicenter, Phase I/II }\end{array}$ & $\begin{array}{l}\text { Patients suffering from advanced, } \\
\text { recurrent or metastatic gastrointestinal } \\
\text { adenocarcinoma }\end{array}$ & Ongoing & Phase I/II \\
\hline $2014-004349-29$ & $\begin{array}{l}\text { Mesenchymal stem cells for radiation-induced } \\
\text { xerostomia (MESRIX) in previous HPV-positive } \\
\text { oropharyngeal head and neck cancer patients }\end{array}$ & $\begin{array}{l}\text { Participants with xerostomia (International } \\
\text { Classification of Diseases-10: DQ 838A) } \\
\text { and oropharyngeal cancer (DC I0) }\end{array}$ & Ongoing & \\
\hline
\end{tabular}

Abbreviations: HPV, human papillomavirus; MSCs, mesenchymal stem cells.

\section{Disclosure}

The authors report no conflicts of interest in this work.

\section{References}

1. Pittenger MF, Mackay AM, Beck SC, et al. Multilineage potential of adult human mesenchymal stem cells. Science. 1999;284(5411): 143-147.

2. Zvaifler NJ, Marinova-Mutafchieva L, Adams G, et al. Mesenchymal precursor cells in the blood of normal individuals. Arthritis Res. 2000; 2(6):477-488.

3. Zuk PA, Zhu M, Mizuno H, et al. Multilineage cells from human adipose tissue: implications for cell-based therapies. Tissue Eng. 2001;7(2): 211-228.

4. Corsten MF, Shah K. Therapeutic stem-cells for cancer treatment: hopes and hurdles in tactical warfare. Lancet Oncol. 2008;9(4):376-384.

5. Prockop DJ. Marrow stromal cells as stem cells for nonhematopoietic tissues. Science. 1997;276(5309):71-74.

6. Jackson WM, Nesti LJ, Tuan RS. Concise review: clinical translation of wound healing therapies based on mesenchymal stem cells. Stem Cells Transl Med. 2012;1(1):44-50.

7. Meuleman N, Tondreau T, Ahmad I, et al. Infusion of mesenchymal stromal cells can aid hematopoietic recovery following allogeneic hematopoietic stem cell myeloablative transplant: a pilot study. Stem Cells Dev. 2009;18(9):1247-1252.

8. Kornblit B, Leisenring WM, Santos EB, et al. Safety of treatment with DLA-identical or unrelated mesenchymal stromal cells in DLA-identical canine bone marrow transplantation. Chimerism. 2013;4(3):95-101.

9. Perico N, Casiraghi F, Introna M, et al. Autologous mesenchymal stromal cells and kidney transplantation: a pilot study of safety and clinical feasibility. Clin J Am Soc Nephrol. 2011;6(2):412-422.

10. Reinders ME, de Fijter JW, Roelofs H, et al. Autologous bone marrowderived mesenchymal stromal cells for the treatment of allograft rejection after renal transplantation: results of a phase I study. Stem Cells Transl Med. 2013;2(2):107-111.

11. Teo AK, Vallier L. Emerging use of stem cells in regenerative medicine. Biochem J. 2010;428(1):11-23.

12. Roobrouck VD, Clavel C, Jacobs SA, et al. Differentiation potential of human postnatal mesenchymal stem cells, mesoangioblasts, and multipotent adult progenitor cells reflected in their transcriptome and partially influenced by the culture conditions. Stem Cells. 2011;29(5): 871-882.

13. Roobrouck VD, Vanuytsel K, Verfaillie CM. Concise review: culture mediated changes in fate and/or potency of stem cells. Stem Cells. 2011; 29(4):583-589.

14. Dominici M, Le Blanc K, Mueller I, et al. Minimal criteria for defining multipotent mesenchymal stromal cells. The International Society for Cellular Therapy position statement. Cytotherapy. 2006;8(4): 315-317.

15. Caplan AI. Mesenchymal stem cells. J Orthop Res. 1991;9(5):641-650.
16. Sacchetti B, Funari A, Michienzi S, et al. Self-renewing osteoprogenitors in bone marrow sinusoids can organize a hematopoietic microenvironment. Cell. 2007;131(2):324-336.

17. Zhang D, Fan GC, Zhou X, et al. Over-expression of CXCR4 on mesenchymal stem cells augments myoangiogenesis in the infarcted myocardium. J Mol Cell Cardiol. 2008;44(2):281-292.

18. Zhuang Y, Chen $\mathrm{X}, \mathrm{Xu} \mathrm{M}$, et al. Chemokine stromal cell-derived factor $1 /$ CXCL12 increases homing of mesenchymal stem cells to injured myocardium and neovascularization following myocardial infarction. Chin Med J (Engl). 2009;122(2):183-187.

19. Ryu CH, Park SA, Kim SM, et al. Migration of human umbilical cord blood mesenchymal stem cells mediated by stromal cell-derived factor-1/CXCR4 axis via Akt, ERK, and p38 signal transduction pathways. Biochem Biophys Res Commun. 2010;398(1):105-110.

20. Kortesidis A, Zannettino A, Isenmann S, et al. Stromal-derived factor-1 promotes the growth, survival, and development of human bone marrow stromal stem cells. Blood. 2005;105(10):3793-3801.

21. Honczarenko M, Le Y, Swierkowski M, et al. Human bone marrow stromal cells express a distinct set of biologically functional chemokine receptors. Stem Cells. 2006;24(4):1030-1041.

22. Rombouts WJ, Ploemacher RE. Primary murine MSC show highly efficient homing to the bone marrow but lose homing ability following culture. Leukemia. 2003;17(1):160-170.

23. Shi M, Li J, Liao L, et al. Regulation of CXCR4 expression in human mesenchymal stem cells by cytokine treatment: role in homing efficiency in NOD/SCID mice. Haematologica. 2007;92(7):897-904.

24. Ponte AL, Marais E, Gallay N, et al. The in vitro migration capacity of human bone marrow mesenchymal stem cells: comparison of chemokine and growth factor chemotactic activities. Stem Cells. 2007;25(7):1737-1745.

25. Fan H, Zhao G, Liu L, et al. Pre-treatment with IL-1beta enhances the efficacy of MSC transplantation in DSS-induced colitis. Cell Mol Immunol. 2012;9(6):473-481.

26. Klopp AH, Spaeth EL, Dembinski JL, et al. Tumor irradiation increases the recruitment of circulating mesenchymal stem cells into the tumor microenvironment. Cancer Res. 2007;67(24):11687-11695.

27. Mishra PJ, Mishra PJ, Glod JW, et al. Mesenchymal stem cells: flip side of the coin. Cancer Res. 2009;69(4):1255-1258.

28. François S, Bensidhoum M, Mouiseddine M, et al. Local irradiation not only induces homing of human mesenchymal stem cells at exposed sites but promotes their widespread engraftment to multiple organs: a study of their quantitative distribution after irradiation damage. Stem Cells. 2006;24(4):1020-1029.

29. Dwyer RM, Khan S, Barry FP, et al. Advances in mesenchymal stem cellmediated gene therapy for cancer. Stem Cell Res Ther. 2010;1(3):25.

30. Kidd S, Caldwell L, Dietrich M, et al. Mesenchymal stromal cells alone or expressing interferon- $\beta$ suppress pancreatic tumors in vivo, an effect countered by anti-inflammatory treatment. Cytotherapy. 2010;12(5): 615-625.

31. Maestroni GJ, Hertens E, Galli P. Factor(s) from nonmacrophage bone marrow stromal cells inhibit Lewis lung carcinoma and B16 melanoma growth in mice. Cell Mol Life Sci. 1999;55(4):663-667. 
32. Qiao L, Xu Z, Zhao T, et al. Suppression of tumorigenesis by human mesenchymal stem cells in a hepatoma model. Cell Res. 2008;18(4): 500-507.

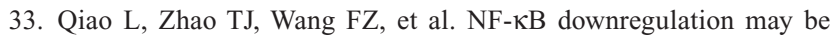
involved the depression of tumor cell proliferation mediated by human mesenchymal stem cells. Acta Pharmacol Sin. 2008;29(3):333-340.

34. Wong RS. Mesenchymal stem cells: angels or demons? J Biomed Biotechnol. 2011;2011:459510.

35. Conrad C, Husemann Y, Niess H, et al. Linking transgene expression of engineered mesenchymal stem cells and angiopoietin-1-induced differentiation to target cancer angiogenesis. Ann Surg. 2011;253(3): 566-571.

36. Zischek C, Niess H, Ischenko I, et al. Targeting tumor stroma using engineered mesenchymal stem cells reduces the growth of pancreatic carcinoma. Ann Surg. 2009;250(5):747-753.

37. Niess H, Bao Q, Conrad C, et al. Selective targeting of genetically engineered mesenchymal stem cells to tumor stroma microenvironments using tissue-specific suicide gene expression suppresses growth of hepatocellular carcinoma. Ann Surg. 2011;254(5):767-774; discussion 774-775.

38. Zhu W, Xu W, Jiang R, et al. Mesenchymal stem cells derived from bone marrow favor tumor cell growth in vivo. Exp Mol Pathol. 2006;80(3): 267-274.

39. Djouad F, Plence P, Bony C, et al. Immunosuppressive effect of mesenchymal stem cells favors tumor growth in allogeneic animals. Blood. 2003;102(10):3837-3844.

40. Li GC, Ye QH, Xue YH, et al. Human mesenchymal stem cells inhibit metastasis of a hepatocellular carcinoma model using the MHCC97-H cell line. Cancer Sci. 2010;101(12):2546-2553.

41. Tian LL, Yue W, Zhu F, et al. Human mesenchymal stem cells play a dual role on tumor cell growth in vitro and in vivo. J Cell Physiol. 2011;226(7):1860-1867.

42. Uccelli A, Pistoia V, Moretta L. Mesenchymal stem cells: a new strategy for immunosuppression? Trends Immunol. 2007;28(5):219-226.

43. Ashkenazi A, Pai RC, Fong S, et al. Safety and antitumor activity of recombinant soluble Apo2 ligand. J Clin Invest. 1999;104(2): $155-162$.

44. Trinchieri G. Interleukin-12 and the regulation of innate resistance and adaptive immunity. Nat Rev Immunol. 2003;3(2):133-146.

45. Gately MK, Renzetti LM, Magram J, et al. The interleukin-12/ interleukin-12-receptor system: role in normal and pathologic immune responses. Annu Rev Immunol. 1998;16:495-521.

46. Chen XC, Wang R, Zhao X, et al. Prophylaxis against carcinogenesis in three kinds of unestablished tumor models via IL12-gene-engineered MSCs. Carcinogenesis. 2006;27(12):2434-2441.

47. Klebanoff CA, Finkelstein SE, Surman DR, et al. IL-15 enhances the in vivo antitumor activity of tumor-reactive CD8+ T cells. Proc Natl Acad Sci U S A. 2004;101(7):1969-1974.

48. Watkins SK, Egilmez NK, Suttles J, et al. IL-12 rapidly alters the functional profile of tumor-associated and tumor-infiltrating macrophages in vitro and in vivo. J Immunol. 2007;178(3):1357-1362.

49. Watkins SK, Li B, Richardson KS, et al. Rapid release of cytoplasmic IL-15 from tumor-associated macrophages is an initial and critical event in IL-12-initiated tumor regression. Eur J Immunol. 2009;39(8): 2126-2135.

50. Waldmann TA. The biology of interleukin-2 and interleukin-15: implications for cancer therapy and vaccine design. Nat Rev Immunol. 2006;6(8):595-601.

51. Sneller MC, Kopp WC, Engelke KJ, et al. IL-15 administered by continuous infusion to rhesus macaques induces massive expansion of CD8+ T effector memory population in peripheral blood. Blood. 2011;118(26):6845-6848.

52. Weiss JM, Back TC, Scarzello AJ, et al. Successful immunotherapy with IL-2/anti-CD40 induces the chemokine-mediated mitigation of an immunosuppressive tumor microenvironment. Proc Natl Acad Sci US A. 2009;106(46):19455-19460.
53. Jing W, Chen Y, Lu L, et al. Human umbilical cord blood-derived mesenchymal stem cells producing IL15 eradicate established pancreatic tumor in syngeneic mice. Mol Cancer Ther. 2014;13(8):2127-2137.

54. Jonasch E, Haluska FG. Interferon in oncological practice: review of interferon biology, clinical applications, and toxicities. Oncologist. 2001;6(1):34-55.

55. Kirkwood JM, Ernstoff MS. Interferons in the treatment of human cancer. J Clin Oncol. 1984;2(4):336-352.

56. Fang JY, Al-Suwayeh SA. Nanoparticles as delivery carriers for anticancer prodrugs. Expert Opin Drug Deliv. 2012;9(6):657-669.

57. You MH, Kim WJ, Shim W, et al. Cytosine deaminase-producing human mesenchymal stem cells mediate an antitumor effect in a mouse xenograft model. J Gastroenterol Hepatol. 2009;24(8):1393-1400.

58. Moolten FL. Tumor chemosensitivity conferred by inserted herpes thymidine kinase genes: paradigm for a prospective cancer control strategy. Cancer Res. 1986;46(10):5276-5281.

59. Rubsam LZ, Davidson BL, Shewach DS. Superior cytotoxicity with ganciclovir compared with acyclovir and 1-beta-D-arabinofuranosylthymine in herpes simplex virus-thymidine kinase-expressing cells: a novel paradigm for cell killing. Cancer Res. 1998;58(17):3873-3882.

60. Craperi D, Vicat JM, Nissou MF, et al. Increased bax expression is associated with cell death induced by ganciclovir in a herpes thymidine kinase gene-expressing glioma cell line. Hum Gene Ther. 1999;10(4): 679-688.

61. Ishii-Morita H, Agbaria R, Mullen CA, et al. Mechanism of 'bystander effect' killing in the herpes simplex thymidine kinase gene therapy model of cancer treatment. Gene Ther. 1997;4(3):244-251.

62. Mesnil M, Piccoli C, Tiraby G, et al. Bystander killing of cancer cells by herpes simplex virus thymidine kinase gene is mediated by connexins. Proc Natl Acad Sci USA. 1996;93(5):1831-1835.

63. Mueller LP, Luetzkendorf J, Widder M, et al. TRAIL-transduced multipotent mesenchymal stromal cells (TRAIL-MSC) overcome TRAIL resistance in selected CRC cell lines in vitro and in vivo. Cancer Gene Ther. 2011;18(4):229-239.

64. Luetzkendorf J, Mueller LP, Mueller T, et al. Growth inhibition of colorectal carcinoma by lentiviral TRAIL-transgenic human mesenchymal stem cells requires their substantial intratumoral presence. $J$ Cell Mol Med. 2010;14(9):2292-2304.

65. Grisendi G, Bussolari R, Cafarelli L, et al. Adipose-derived mesenchymal stem cells as stable source of tumor necrosis factor-related apoptosis-inducing ligand delivery for cancer therapy. Cancer Res. 2010;70(9):3718-3729.

66. Moniri MR, Sun XY, Rayat J, et al. TRAIL-engineered pancreas-derived mesenchymal stem cells: characterization and cytotoxic effects on pancreatic cancer cells. Cancer Gene Ther. 2012;19(9):652-658.

67. Deng Q, Zhang Z, Feng X, et al. TRAIL-secreting mesenchymal stem cells promote apoptosis in heat-shock-treated liver cancer cells and inhibit tumor growth in nude mice. Gene Ther. 2014;21(3):317-327.

68. Yan C, Yang M, Li Z, et al. Suppression of orthotopically implanted hepatocarcinoma in mice by umbilical cord-derived mesenchymal stem cells with sTRAIL gene expression driven by AFP promoter. Biomaterials. 2014;35(9):3035-3043.

69. Sun XY, Nong J, Qin K, et al. MSC(TRAIL)-mediated HepG2 cell death in direct and indirect co-cultures. Anticancer Res. 2011;31(11): 3705-3712.

70. Xin L, Xu R, Zhang Q, et al. Kringle 1 of human hepatocyte growth factor inhibits bovine aortic endothelial cell proliferation stimulated by basic fibroblast growth factor and causes cell apoptosis. Biochem Biophys Res Commun. 2000;277(1):186-190.

71. Kuba K, Matsumoto K, Ohnishi K, et al. Kringle 1-4 of hepatocyte growth factor inhibits proliferation and migration of human microvascular endothelial cells. Biochem Biophys Res Commun. 2000;279(3): 846-852.

72. Zhu Y, Cheng M, Yang Z, et al. Mesenchymal stem cell-based NK4 gene therapy in nude mice bearing gastric cancer xenografts. Drug Des Devel Ther. 2014;8:2449-2462. 
73. Francois A, Milliat F, Guipaud O, et al. Inflammation and immunity in radiation damage to the gut mucosa. Biomed Res Int. 2013;2013: 123241.

74. Chapel A, Bertho JM, Bensidhoum M, et al. Mesenchymal stem cells home to injured tissues when co-infused with hematopoietic cells to treat a radiation-induced multi-organ failure syndrome. J Gene Med. 2003;5(12):1028-1038.

75. Zielske SP, Livant DL, Lawrence TS. Radiation increases invasion of gene-modified mesenchymal stem cells into tumors. Int J Radiat Oncol Biol Phys. 2009;75(3):843-853.
76. Knoop K, Kolokythas M, Klutz K, et al. Image-guided, tumor stromatargeted 131I therapy of hepatocellular cancer after systemic mesenchymal stem cell-mediated NIS gene delivery. Mol Ther. 2011;19(9): 1704-1713.

77. Chen MF, Lin CT, Chen WC, et al. The sensitivity of human mesenchymal stem cells to ionizing radiation. Int J Radiat Oncol Biol Phys. 2006;66(1):244-253.

\section{Publish your work in this journal}

Gastrointestinal Cancer: Targets and Therapy is an international, peer-reviewed, open access journal focusing on gastro-intestinal cancer research, identification of therapeutic targets and the optima use of preventative and integrated treatment interventions to achieve improved outcomes, enhanced survival and quality of life for the cancer patient. The manuscript management system is completely online and includes a very quick and fair peer-review system. Visit http://www.dovepress.com/testimonials.php to read real quotes from published authors.

Submit your manuscript here: http://www.dovepress.com/gastro-intestinal-cancer-targets-and-therapy-journal 